Acta Theriologica 41 (2): 113-126, 1996.

PL ISSN 0001-7051

\title{
Otter Lutra lutra distribution in Poland
}

\author{
Marcin BRZEZIŃSKI, Jerzy ROMANOWSKI, Jakub P. CYGAN \\ and Bernard PABIN
}

Brzeziński M., Romanowski J., Cygan J. P. and Pabin B. 1996. Otter Lutra lutra distribution in Poland. Acta Theriologica 41: 113-126.

In a field survey of Poland in 1991-1994, signs of otters Lutra lutra (Linnaeus, 1758) were found at $1655(79.5 \%)$ of the 2083 investigated sites. Widespread in most of the country, otters were especially common in the lakelands (N Poland), along the western and eastern borders, and in the Karpaty/Carpathian Mts (SE Poland). Two large areas with only few positive sites were identified in Slask/Silesia (SW Poland) and central Poland. Otters inhabit the majority of large rivers in Poland, except some sections of Odra/Oder and Wisła/Vistula. The dynamics of the otter population in Poland in recent decades is difficult to investigate, mainly due to the scarce questionnaire data from the sixties and seventies, however, present records suggest that the otter has extended its range, and is no longer an endangered species in Poland.

Department of Ecology, University of Warsaw, Krakowskie Przedmieście 26/28, 00-927 Warszawa, Poland (MB, BP); Institute of Ecology, Polish Academy of Sciences, 05-092 Łomianki, Poland (JR, JPC)

Key words: Lutra lutra, distribution, national survey, Poland

\section{Introduction}

Previous data on otter Lutra lutra (Linnaeus, 1758) occurrence in Poland were scarce since no national field survey had been undertaken. Several authors reported on the results of inquires, indicating that otters occur unevenly in the whole country (Pielowski 1980, Buchalczyk 1983, Romanowski 1984, Sikora 1984). Some areas had been identified as inhabited by relatively large otter populations, eg lakelands (N Poland) and Karpaty/Carpathian Mts (SE Poland). A few regional studies carried out in Pomorze Zachodnie/West Pomerania (Włodek 1980), the Romincka Forest (Brzeziński 1991a) and the Bieszczady Mts (Brzeziński 1991b) revealed many otter localities.

Reports on otter distribution, published at the beginning of the 1980s, indicated a decline of otter numbers in Poland (Romanowski 1984, Bieniek 1988). The species was described as rare and endangered in the Polish Red Data Book of Animals (Bieniek 1992) as well as in recent regional reports (Jamrozy 1994). These authors mentioned that only in some areas the otter populations seemed to increase in numbers. Over the last decade an increase in otter numbers has been observed in many regions (Włodek et al. 1989 and pers. inf.). 
Scarce data and the obscure character of some Polish publications resulted in a false picture of otter abundance in central Europe. Macdonald and Mason (1990b, 1994) reviewing the conflicting data available suggested that the species was absent from much of the country (especially in western Poland), whereas it was widely distributed in nearby East Germany.

The aim of the first field national otter survey, was to create a detailed map of the otter distribution in Poland, and compare these data to the results obtained in other European countries.

\section{Study area}

Poland $\left(312265 \mathrm{~km}^{2}\right)$ lies in the area of Northern European Plain, between $54^{\circ} 50^{\prime}$ and $49^{\circ} 00^{\prime} \mathrm{N}$, and $14^{\circ} 07^{\prime}$ and $24^{\circ} 08^{\prime} \mathrm{E}$. Farmlands comprise $61.1 \%$ of the country area, forests $-28.0 \%$, water bodies $-2.6 \%$, urban areas $-5.8 \%$, and barrens $-1.6 \%$. The average elevation reaches $173 \mathrm{~m}$ above sea level; $91.3 \%$ area of the country lies between $0-300 \mathrm{~m}$. Uplands $(300-500 \mathrm{~m})$ and mountains $(>500 \mathrm{~m})$ are situated in the south and cover respectively 5.7 and $2.9 \%$ of Poland's territory. In the central Poland, where lowlands dominate, the river system is well developed but there are almost no lakes. Lakelands (in the north) were created during the last glaciation. There are 9300 lakes in Poland larger than 1 ha and they cover $3200 \mathrm{~km}^{2}$ ( $1 \%$ of the country). Most of them $(89 \%)$ are concentrated in the northern and north-western Poland (Fig. 1A). Over 100 artificial reservoirs cover an area of more then $450 \mathrm{~km}^{2}$. Stripe of lowland extends at the side of the Baltic See. Deltas were formed in the mouth of some rivers. Several coastal lakes can be found along the Baltic See shore (Kondracki 1988).

The Baltic Sea basin comprises $99.7 \%$ of the area of Poland; Wisa/Vistula catchment $-54 \%$, Odra/Oder catchment $-33.9 \%$, Baltic Sea tributaries $-9.3 \%$, and Niemen catchment $-0.8 \%$. Catchments of Dnestr, Danube and Elbe cover only $0.3 \%$ of Poland's territory. The longest rivers are: Wisła - $1047 \mathrm{~km}$, Odra - $854 \mathrm{~km}(742 \mathrm{~km}$ in Poland), Warta - $808 \mathrm{~km}$, Bug - $722 \mathrm{~km}(587 \mathrm{~km}$ in Poland), and Narew - $484 \mathrm{~km}$ (448 km in Poland) (Kondracki 1988).

\section{Materials and methods}

The field survey was based on a UTM $10 \mathrm{~km}$ square grid (see Macdonald 1983). In each square one site was investigated. Sites were chosen according to 1:100 000 maps for presence of suitable habitats and for ease of access. Searching usually started at a bridge. Generally at each site, a maximum distance of $600 \mathrm{~m}$ was searched for the tracks and spraints of otters. If no otter signs were found the site was recorded as negative. At each site as soon as otter tracks or spraints were found the search was stopped and the site was confirmed as positive. To improve the reliability of the survey in areas with low numbers of otter signs, the search was extended up to $1000 \mathrm{~m}$ at $92(4.4 \%)$ sites, and spot checks at additional bridges in each negative square were performed (Romanowski et al. 1996).

Between October 1991 and May 1994, 2083 sites were visited, including upland and lowland rivers and streams, canals, reservoirs and lakes. The field study was undertaken in all seasons of the year except during periods with snow cover. Altogether 155 days were spent in the field. The survey covered the whole country and only about 50 squares (1.7\% of area of Poland) with suitable habitats were omitted. Squares without water bodies were not surveyed. For the study of otter distribution the area of Poland was divided into 13 catchments (Fig. 1B).

The habitat quality at both, survey sites (a) and corresponding $10 \times 10 \mathrm{~km}$ UTM squares (b) was described to identify environmental factors that may have affected the otter presence or absence. 


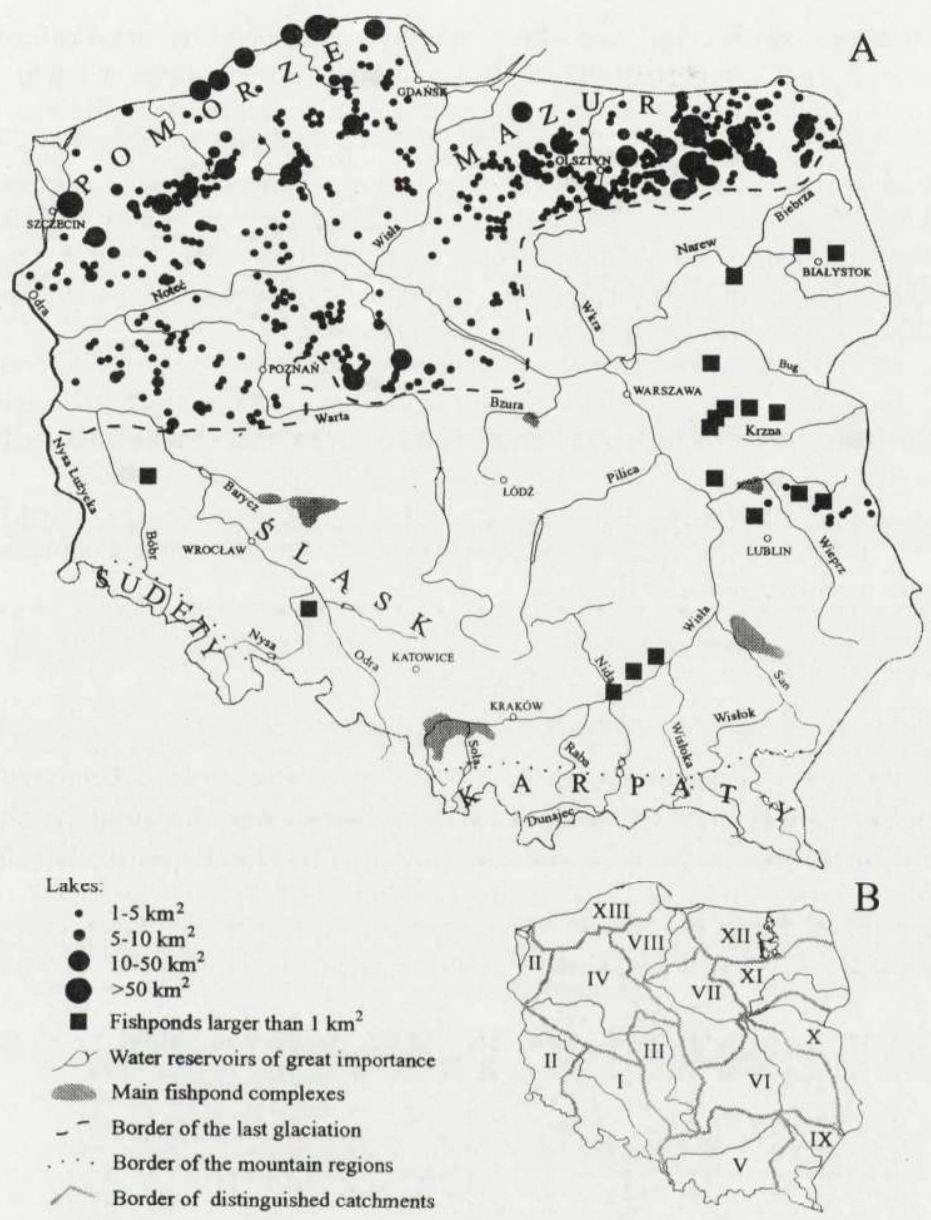

Fig. 1. (A) Distribution of main water bodies in Poland (after Leszczycki 1978, modified). (B) Catchment areas in Poland: I - Odra (upper), II - Odra (lower), III - Warta (upper), IV - Warta (lower), V - Wisła (upper A), VI - Wisła (upper B), VII - Wisła (middle), VIII - Wisła (lower), IX - San, X Bug, XI - Narew, XII - Mazury, XIII - Pomorze.

Direct field observations during the search for otter signs were used to describe the survey sites. UTM squares were characterised on the basis of 1:100 000 maps. Data on water pollution were obtained for 52 large Polish rivers (Korol et al. 1994). The following environmental factors were analysed:

1. Water quality: (a) At each site visited, water quality was observed and classified according to its transparency, colour and smell into two categories: (i) good quality, (ii) bad quality. (b) At 443 sites for which data on water pollution were available (Korol et al. 1994), water quality was classified into two categories according to standards set by the State Inspection of Environmental Protection: (i) 1st, 2nd and 3rd class (slight to moderate pollution), (ii) outwith acceptable limits (high pollution). This classification was made separately for two groups of pollutants: organic pollution [measured by Biochemical Oxygen Demand (BOD), Chemical Oxygen Demand (COD), and dissolved organic substances] and chemical pollution containing phenols, chlorines, sulphur oxides, or heavy metals. 
2. The urbanisation gradient: (a) Each site visited was classified into three categories according to number of buildings recorded adjacent to the bank: (i) many (large village or town), (ii) few (single farms), (iii) none. (b) In each square the total length of banks covered by buildings was estimated based on maps and classified into five categories: (i) $0 \%$, (ii) $<10 \%$, (iii) $10-50 \%$, (iv) $>50 \%$, (v) $100 \%$.

3. River regulation: (a) Each site visited was classified into three categories according to the river bank characteristics (ie construction, substrate, slope) and degree of human interference of river current: (i) totally regulated (ditches, channels, etc), (ii) partially regulated, (iii) not regulated. (b) In each square the total length of river regulation was estimated based on maps and classified in five categories: (i) $0 \%$, (ii) $<10 \%$, (iii) $10-50 \%$, (iv) $>50 \%$, (v) $100 \%$.

4. Vegetation cover: (a) Each site visited was classified into three categories according to tree and bush cover: (i) dense cover (rows or clumps of trees or bushes), (ii) moderate cover (single trees and bushes), (iii) none. (b) In each square the forestation of banks was estimated based on maps and classified into five categories: (i) $0 \%$, (ii) $<10 \%$, (iii) $10-50 \%$, (iv) $>50 \%$, (v) $100 \%$.

The relationship between environmental factors and the otter presence was tested with the $G$-test for independence (Statgraphics 5.0). The analysis was made for the whole Poland and each of 13 identified catchment areas (see Fig. 1B).

\section{Results}

A total of 2083 UTM squares were visited and signs of otters were found at 1655 (79.5\%) (Fig. 2). The frequency of positive sites was highest in the lakelands (NW and N Poland), along the eastern border, and in the Karpaty Mts (SE Poland)

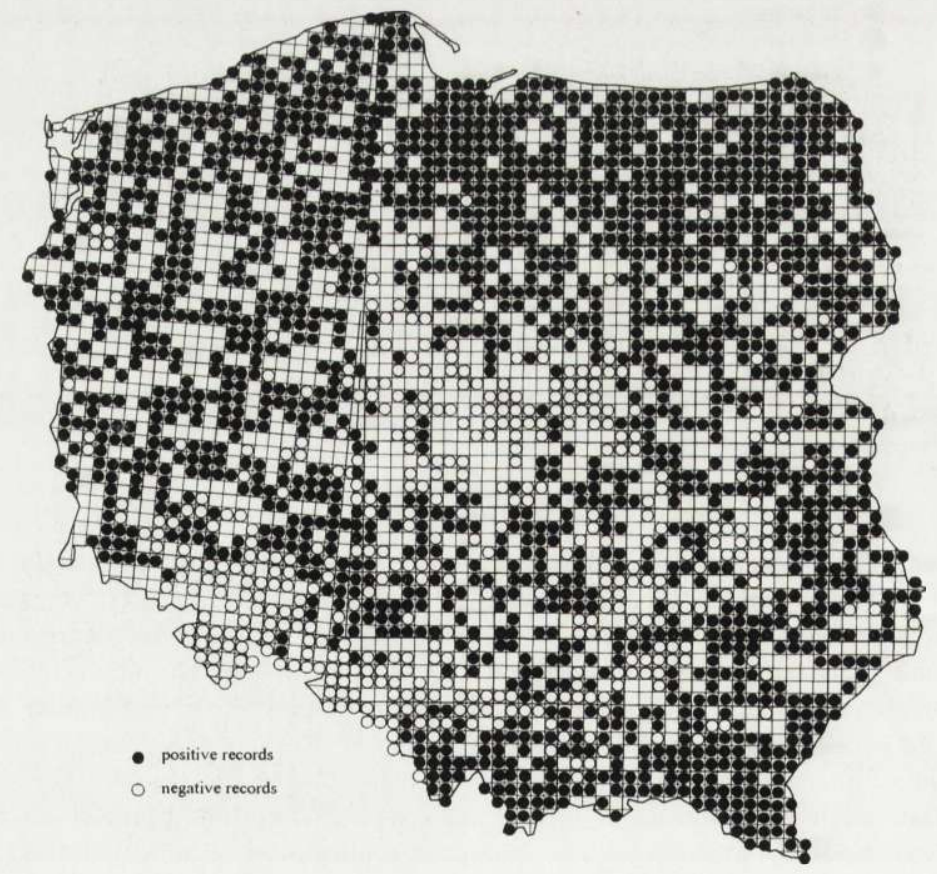

Fig. 2. Otter Lutra lutra survey in Poland in $10 \times 10 \mathrm{~km}$ squares of UTM grid. 
(Fig. 3). Two large areas with few signs of otter presence were identified in Śląsk/Silesia (SW Poland) and in central Poland.

In the thirteen catchment areas identified the percentage of positive sites varied from $42.2 \%$ in the upper Odra catchment (I) to $100.0 \%$ in Mazury/Masurian (XII) and Pomorze/Pomerania (XIII) lakelands (Table 1). Otters did not inhabit the majority of the western tributaries of the upper Odra (including nearly the whole Nysa Kłodzka). Relatively low numbers of positive sites were recorded in the catchment areas of central Poland such as upper.Warta (III), and upper and middle Wisła (V, VI, VII). East of the Wisła [eastern Wisła tributaries, Narew (XI) and Bug (X) catchments] the otter was common, except for a small region in the western part of the Wyżyna Lubelska/Lublin Upland. On several small western tributaries of the Wisła no otter signs were found. The whole Bzura basin (except for the river Rawka) in the middle Wisła catchment area (VII) was not inhabited by otters. In the catchment areas of lower sections of the Odra (II), Warta (IV), and Wisła (VIII) the frequency of positive sites exceeded $90 \%$. All small rivers discharging directly to the Baltic See in Pomorze (XIII) were inhabited by otters. In the Karpaty they were present on all small and medium sized rivers in the catchment areas of upper Wisła (V) and San (IX). By contrast, otters were absent from the most of Sudety (catchment areas of upper Odra). Signs of otters were found on all large rivers except for the upper Odra and upper Wisła (Fig. 4).

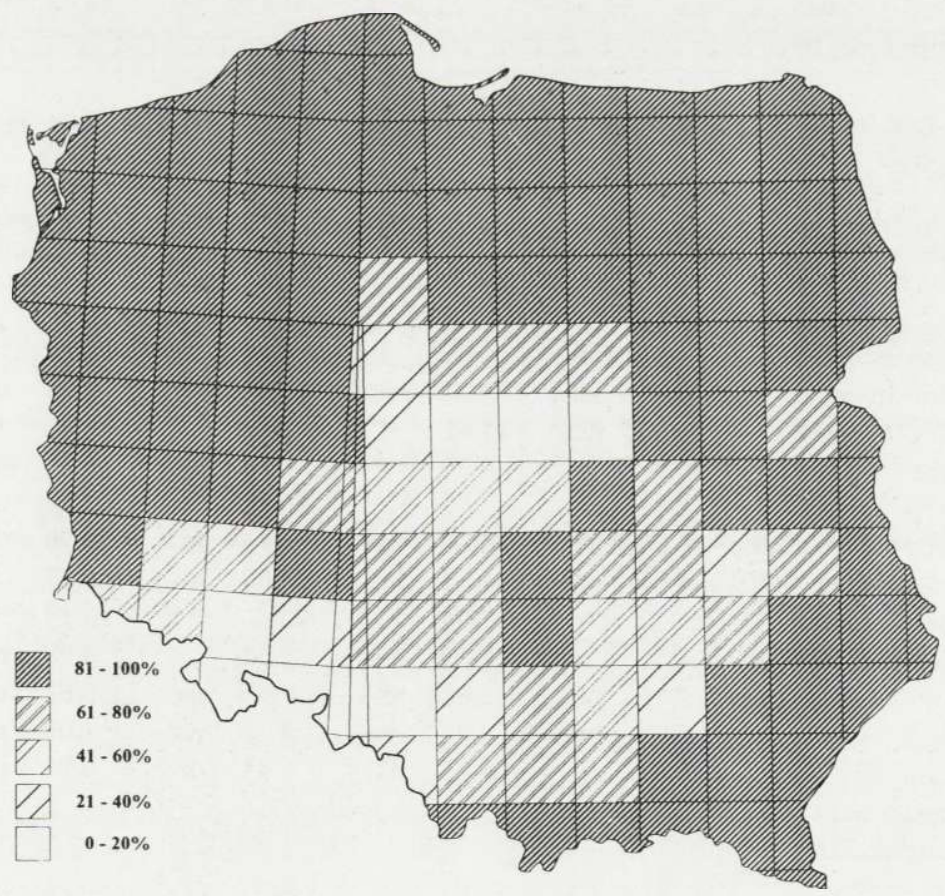

Fig. 3. Frequency of positive records of otter Lutra lutra in $50 \times 50 \mathrm{~km}$ squares. 
Table 1. Percentage of positive sites in different catchments in Poland (see Fig. 1B for division of Poland into catchments) and statistical analysis of factors affecting otter distribution in Poland (G-test, Statgraphics 5.0: ${ }^{*}-p<0.01,{ }^{* *}-p<0.001,{ }^{* * *}-p<0.0001$, ns - not significant).

\begin{tabular}{|c|c|c|c|c|c|c|c|c|c|c|c|c|}
\hline \multirow[t]{3}{*}{ Region } & \multirow{3}{*}{$\begin{array}{l}\text { Number } \\
\text { of sites }\end{array}$} & \multirow{3}{*}{$\begin{array}{c}\text { Positive } \\
\text { sites } \\
(\%)\end{array}$} & \multicolumn{6}{|c|}{ Water quality } & \multicolumn{4}{|c|}{ Urbanisation gradient } \\
\hline & & & \multicolumn{2}{|c|}{$\begin{array}{c}\text { organic } \\
\text { pollution }\end{array}$} & \multicolumn{2}{|c|}{$\begin{array}{l}\text { chemical } \\
\text { pollution }\end{array}$} & \multicolumn{2}{|c|}{$\begin{array}{l}\text { at survey } \\
\text { site }\end{array}$} & \multicolumn{2}{|c|}{$\begin{array}{l}\text { in UTM } \\
\text { square }\end{array}$} & \multicolumn{2}{|c|}{$\begin{array}{l}\text { at survey } \\
\text { site }\end{array}$} \\
\hline & & & $G$ & $p$ & $G$ & $p$ & $G$ & $p$ & $G$ & $p$ & $G$ & $p$ \\
\hline Odra (upper) I & 218 & 42.2 & 3.14 & ns & 0.17 & ns & 5.76 & $*$ & 22.35 & $* * *$ & 7.79 & $*$ \\
\hline Odra (lower) II & 134 & 91.0 & & & & & 8.08 & $* *$ & 0.67 & ns & 4.71 & ns \\
\hline Warta (upper) III & 115 & 54.8 & 1.67 & ns & 1.67 & ns & 3.06 & ns & 2.84 & ns & 0.42 & ns \\
\hline Warta (lower) IV & 195 & 92.8 & 1.97 & ns & 0.46 & ns & 5.90 & $*$ & 11.40 & $* *$ & 22.80 & $* * *$ \\
\hline Wisła (upper A) V & 247 & 70.0 & 13.82 & $* * *$ & 10.87 & $* * *$ & 8.34 & $* *$ & 5.94 & ns & 4.04 & $*$ \\
\hline Wisła (upper B) VI & 218 & 72.0 & 25.53 & $* * *$ & 1.43 & ns & 11.16 & $* * *$ & 11.11 & $*$ & 0.83 & ns \\
\hline Wisła (middle) VII & 159 & 63.5 & 25.00 & $* * *$ & & & 21.06 & $* * *$ & 4.16 & ns & 2.44 & ns \\
\hline Wisła (lower) VIII & 108 & 97.2 & & & & & 34.30 & $* * *$ & 1.80 & ns & 0.46 & ns \\
\hline San IX & 109 & 93.6 & & & & & 6.44 & $*$ & 6.91 & ns & 0.07 & ns \\
\hline Bug X & 120 & 88.3 & & & & & 5.55 & * & 0.84 & ns & 1.62 & ns \\
\hline Narew XI & 155 & 95.5 & & & & & 0.24 & $\mathrm{~ns}$ & 8.13 & $*$ & 0.01 & $\mathrm{~ns}$ \\
\hline Mazury XII & 172 & 100.0 & & & & & & & & & & \\
\hline Pomorze XIII & 133 & 100.0 & & & & & & & & & & \\
\hline Poland & 2083 & 79.5 & 67.54 & $* * *$ & 23.16 & $* * *$ & 123.95 & $* * *$ & 44.68 & $* * *$ & 8.10 & $*$ \\
\hline
\end{tabular}

\begin{tabular}{|c|c|c|c|c|c|c|c|c|}
\hline \multirow[t]{3}{*}{ Region } & \multicolumn{4}{|c|}{ River regulation } & \multicolumn{4}{|c|}{ Vegetation cover } \\
\hline & \multicolumn{2}{|c|}{$\begin{array}{l}\text { in UTM } \\
\text { square }\end{array}$} & \multicolumn{2}{|c|}{$\begin{array}{c}\text { at survey } \\
\text { site }\end{array}$} & \multicolumn{2}{|c|}{$\begin{array}{l}\text { forestration in } \\
\text { UTM square }\end{array}$} & \multicolumn{2}{|c|}{$\begin{array}{l}\text { at survey } \\
\text { site }\end{array}$} \\
\hline & $G$ & $p$ & $G$ & $p$ & $G$ & $p$ & $G$ & $p$ \\
\hline Odra (upper) I & 3.68 & ns & 5.11 & ns & 15.65 & $* *$ & 0.03 & ns \\
\hline Odra (lower) II & 3.09 & ns & 11.61 & $* *$ & 2.33 & ns & 9.96 & $* *$ \\
\hline Warta (upper) III & 10.40 & $*$ & 5.54 & ns & 1.85 & ns & 5.54 & ns \\
\hline Warta (lower) IV & 3.84 & ns & 1.45 & ns & 10.32 & $*$ & 0.013 & ns \\
\hline Wisła (upper A) V & 36.76 & $* * *$ & 36.60 & $* * *$ & 3.75 & ns & 27.70 & $* * *$ \\
\hline Wisła (upper B) VI & 4.64 & ns & 4.34 & ns & 6.56 & ns & 6.67 & $*$ \\
\hline Wisła (middle) VII & 27.79 & $* * *$ & 7.98 & $*$ & 20.60 & $* * *$ & 11.14 & $* * *$ \\
\hline Wisła (lower) VIII & 2.31 & ns & 1.12 & ns & 2.51 & ns & 0.98 & ns \\
\hline San IX & 2.15 & ns & 0.83 & ns & 7.15 & $\mathrm{~ns}$ & 0.67 & ns \\
\hline Bug X & 5.14 & ns & 4.55 & ns & 4.10 & $\mathrm{~ns}$ & 1.69 & ns \\
\hline Narew XI & 5.62 & ns & 0.75 & ns & 3.41 & ns & 0.76 & $\mathrm{~ns}$ \\
\hline \multirow{2}{*}{\multicolumn{9}{|c|}{$\begin{array}{l}\text { Mazury XII } \\
\text { Pomorze XIII }\end{array}$}} \\
\hline & & & & & & & & \\
\hline Poland & 111.44 & $* * *$ & 60.74 & $* * *$ & 90.66 & $* * *$ & 73.00 & $* * *$ \\
\hline
\end{tabular}




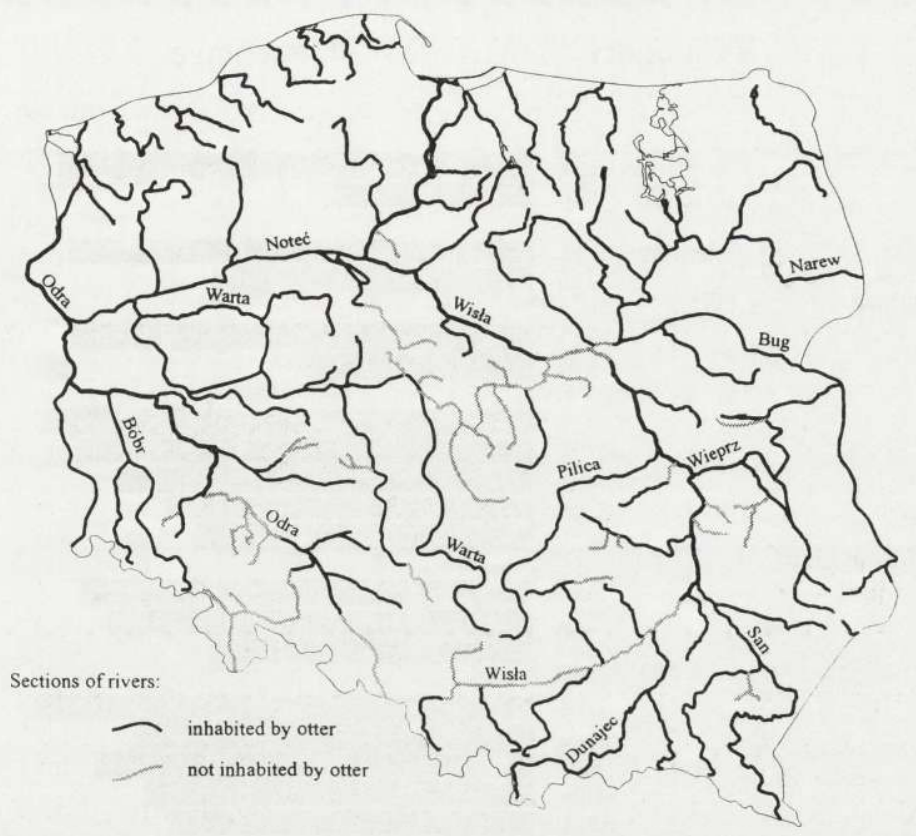

Fig. 4. Distribution of otter Lutra lutra on the rivers in Poland (based on the national survey, with modifications: single negative sites on rivers inhabited by otters are not shown).

All analysed environmental factors have an influence on the otter distribution in Poland (Fig. 5). Importance of these factors varies in the distinguished catchments (Table 1). In these sites where organic and chemical pollution was outwith acceptable limits, otter presence was recorded less often than at sites with 1,2 , or 3 class of water quality (Fig. 5). This relation was most visible for Wisła V catchment where otter distribution could be explained by high levels of both groups of pollutants (Table 1). Water pollution was also the main reason for otter absence in many sites of Wisła VI and VII catchments. In two other polluted catchments: Odra I and Warta III no relations between water quality and otter presence were found. The incidence of otter distribution in relation to the water quality was also confirmed by the field observations at the survey sites. Otter signs were more often recorded at sites where water quality was classified as "good" during the field survey. This relationship was found in 9 catchments and was most significant for all four Wisła catchments.

Densities of human settlements along the banks affected the otter abundance in many areas, however the significance of this factor was smallest among all variables analysed. At the survey sites with many buildings otter signs were found less often than at sites with fewer buildings. Similar relation was found in analysis of settlement densities along the banks in the whole UTM square (Fig. 5). Otter absence was especially affected in Odra I and Warta IV catchments. 


\section{Category Percentage}

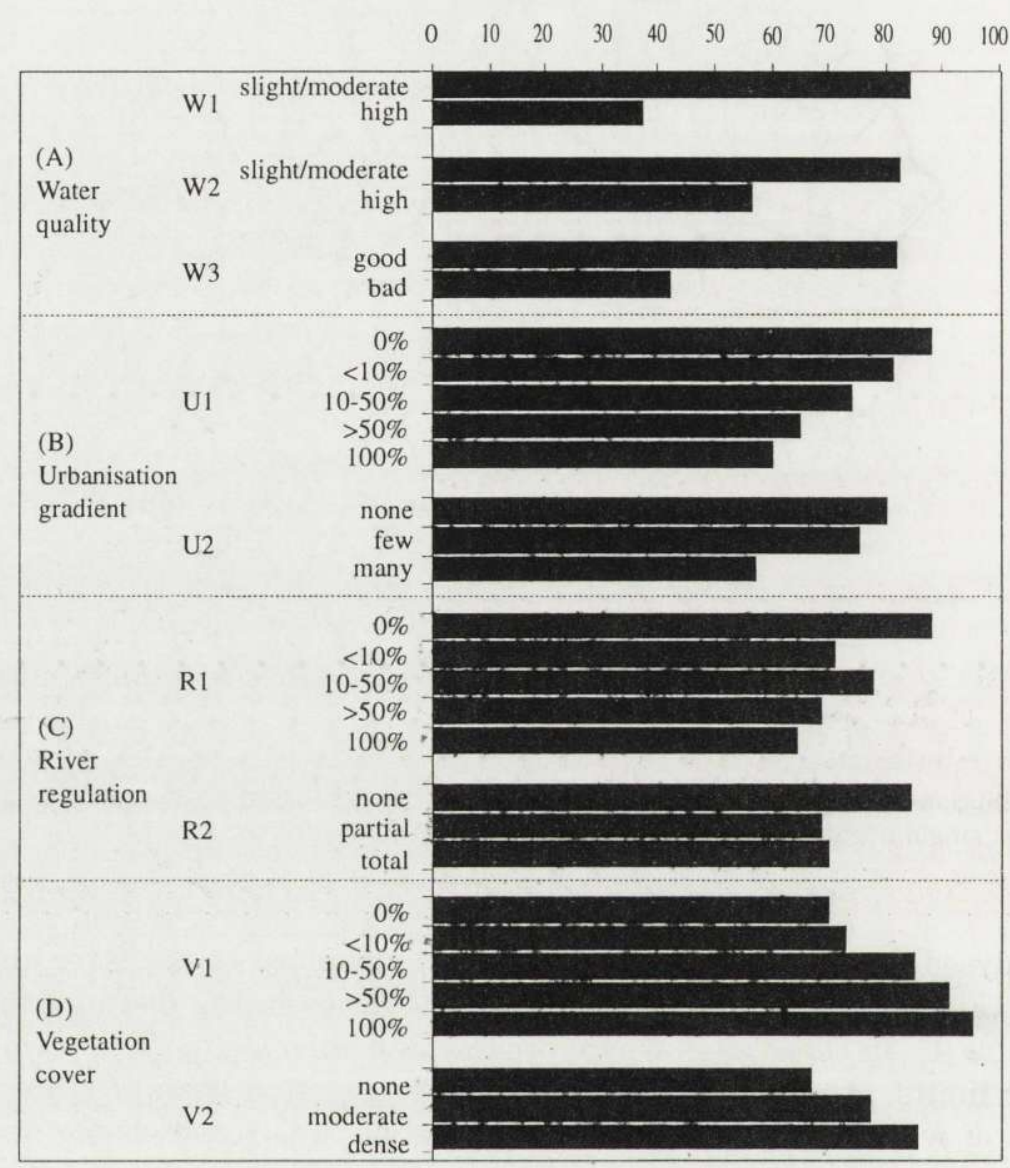

Fig. 5. Factors affecting otter Lutra lutra occurrence in Poland. Percentage of positive records at sites classified according to water quality (A), urbanisation gradient (B), river regulation (C), and vegetation cover (D) (see Materials and methods for details). A: W1 - organic pollution, W2 - chemical pollution, W3 - water quality at survey site. B: U1 - percentage of banks covered by buildings in UTM square, U2 - number of buildings at survey site. C: R1 - percentage of river regulation in UTM square, R2 - river regulation at survey site. D: V1 - forestation of banks in UTM square, V2 vegetation cover at survey site.

Otter signs were less commonly found at those sites where banks were highly regulated both at the surveyed sites and in the whole UTM square. This factor was most important in two Wisła catchments (V and VII).

The riparian vegetation cover was an important factor affecting otter presence at survey sites. At sites with poor cover otter signs were found less often than in sites with dense vegetation. Also, the total length of banks overgrown with forest within each UTM square had a positive influence on the otter abundance (Fig. 5). 


\section{Discussion}

The field survey is recommended as the best method of investigating otter distribution in large areas (Macdonald 1990). Field survey data make it possible to compare otter distribution in particular regions or river basins, but they are not adequate for estimating numbers of animals. For example, the comparison of the percentage of positive sites in two mountain regions; Karpaty and Sudety clearly illustrates the differences in otter abundance. On the other hand the near $100 \%$ frequency of positive sites in lakelands and in Karpaty does not mean that the densities of otters in both regions (with very different habitats) are similar. Otter densities vary due to the type of habitat and food ability (Sidorovich 1991) and the abundance of water bodies in the area. In the standard method, which is based on the $10 \mathrm{~km}$ grid, otter signs were searched for only once in each square, without consideration of the total area of water bodies within the square.

The identification of environmental factors which are affecting otter distribution is one of the most important aims of recent otter studies. Basic habitat requirements of the species have been described but more detailed analyses are still needed. In general, water pollution is known to be the main limiting factor of otter distribution in Europe (Macdonald and Mason 1990a, b). Much evidence indicates that bioaccumulating pollutants, especially PCBs, played the major role in decline of otter numbers in Europe. It has been also suggested that other pollutants ie heavy metals, and water acidification may have some impact on otter abundance (Mason 1989, Macdonald and Mason 1994). Otters are also vulnerable to destruction of riparian habitats. Deforestation, removal of bankside vegetation, channnelisation and other forms of human interference are generally recognised among major factors limiting otter populations. Data collected during field surveys showed that otter distribution and activity was related to well vegetated banks (Jenkins and Burrows 1980, Macdonald and Mason 1983).

Data collected during the national survey demonstrate that all analysed environmental factors have an influence on the otter distribution in Poland. However, their significance varies in different parts of the country. In catchments where the otter was very common ( $80-100 \%$ of positive sites), the negative influence of environmental factors was hard to detect. In such areas the most important factor responsible for otter absence at specific sites could be the high pollution of small waterbodies, observed during the field survey. It seems that in catchments of moderate otter abundance $(40-80 \%$ of positive sites), water pollution is a major factor influencing otter distribution. However, in these catchments several environmental factors affect the occurrence of the species in a pronounced and complex way. This can be observed in catchments of Wisła V, VI, VII and Odra I (Table 1). Despite a very low number of positive sites in the Warta III catchment and high intensity of the potentially limiting variables, only a single environmental factor affecting otter distribution (ie river channelisation) in this area was found. 
The lowest frequency of positive sites was recorded in Odra I catchment which covers part of the Śląsk area, where waters are extremely polluted due to heavy industry and dense human population (GUS 1994, Leszczycki 1994). The lack of correlations between absence of otter and water quality in this catchment is therefore confusing. It can be explained by the fact that here otters were not recorded on numerous sites both on the heavily polluted river Odra and on clean tributaries in Sudety Mts. The reasons for otter absence in Sudety Mts are not clear. The most probable explanation could be the effect of water acidification on food resources and/or high pollution of surrounding areas, that creates ecological barriers for otter expansion. Our data show that in this catchment area the otter absence is easiest to explain by the presence of many human settlements close to the river banks (Table 1).

In catchments of Wisła V, VI, VII the otter is distributed unevenly due to the diversity of habitats. The absence of otter in some areas of Wisła catchments can be explained by the cumulation of negative environmental factors. For example, in Wisła VII catchment in central Poland these factors are heavy water pollution and damage to river banks (ie aforestation and river regulation). In Wyżyna Lubelska/Lublin Upland (part of Wisła VI catchment) water pollution and urbanisation are major limiting factors. In the industrial areas of Wisła V catchment the three main negative factors are water pollution, river regulation and lack of riparian vegetation cover. The absence of otter on the upper section of Wisła results probably from the pollution by Śląsk tributaries.

In general, the otter is widely distributed in those regions which are least transformed by human activities (ie Karpaty, lakelands and forested areas in NE Poland), and it is absent in some industrial and developed districts. However, even in some regions of intensive agriculture ie Nizina Wielkopolska/Wielkopolska Lowland (W Poland) the frequency of positive sites exceeded $80 \%$. One of the most important factors affecting the continuous otter distribution in Poland is the fact that the largest rivers (with their unregulated river beds and seminatural riparian vegetation) provide suitable otter habitats. In the transformed regions of central Poland the large rivers inhabited by otters (Pilica and Warta) have great importance for the distribution of the species by connecting many small tributaries, which alone would not sustain otter populations. The extirpation of the otter in almost the whole Bzura catchment can be attributed to heavy chemical pollution of the surface waters in the area (GUS 1994, Leszczycki 1994). The improvement of water quality of the Bzura would probably allow otters to recolonize the whole catchment which holds some well preserved riparian habitats.

Comparison of the first field survey data to earlier questionnaire information does not enable us to record changes in otter distribution in Poland. It is not clear if the wide distribution of this species in the early 1990s has resulted from an increase in numbers or is due to the application of the more reliable field survey method. For example, questionnaire data collected by Jamrozy (1994) for Karpaty, show that in the late 1980 s otters were present in less than $50 \%$ of the area in 
which the species was found during the national survey. This suggests that the field survey method is much more precise than enquiries. However, there is some evidence of an increase in otter numbers in Poland in the last decade (Włodek et al. 1989, Jamrozy 1994). During the present field study, presence of otters were reported in previously uninhabited areas. In recent years otters have often been found in fish ponds, and owners claimed otter damage to their fish stocks. The presence of otter signs in many sub optimal habitats, such as irrigation canals, may indicate high densities of these animals in optimal habitats over large areas of Poland and dispersal tendencies of the species.

According to our data, in the early 1990s the otter was very common in those regions in which it had been widespread in the $1970 \mathrm{~s}$ - in eastern Pomorze, Mazury and in Karpaty (Buchalczyk 1983, Romanowski 1984). However, in many other areas, now densely populated by otters, such as the Bug, Narew and middle Wisła basins, otters were previously recorded with as low frequency as in central and southwestern Poland (Śląsk), where today otter is very rare or absent. These facts indicate that the picture of the otter distribution in Poland in the 1970s was incomplete. According to present data the most accurate previously published map was prepared by Włodek for Pielowski (1980). The data obtained in the national otter survey show that the otter is widely distributed and should no longer be classified as an endangered species in Poland.

The results of the Polish national survey represent one of the highest percentages of positive sites in continental Europe in comparison with other countries were surveys have been carried out. The only higher percentages of positive sites were recorded for the island population of otters in Ireland - 92\% (Chapman and Chapman 1982), and in Lithuania - 94\% (Baranauskas and Mickevicius 1995). Surveys in Great Britain showed a north-south cline with highest percentage of positive sites (73\%) in Scotland (Green and Green 1980), and only $10 \%$ of positive sites in England (Strachan et al. 1990). Our results compare with $70 \%$ positive sites for Portugal (Macdonald and Mason 1982a), 62\% for Greece (Macdonald and Mason 1982b), 52\% for Hungary (Kemenes 1991), 33\% for Spain (Delibes 1990), 15\% for France (Green and Green 1981), and 9\% for Denmark (Madsen and Nielsen 1986).

Unfortunately, no such comparisons of our results are possible for large areas of central and eastern Europe, where national surveys have not been carried out. Analysis of data on otter occurrence in Poland and in neighbouring countries yields some patterns in distribution of the species in this area. The high abundance of otters along the eastern border of Poland corresponds well with reports on widespread otter populations in neighbouring states of Lithuania and Belarus (Sidorovich and Lauzhel 1992, Mickevicius 1993, Baranauskas and Mickevicius 1995). The density of otters in Belarus is thought to be high despite the marked decline of the population since the mid-1980s (Sidorovich and Lauzhel 1992). Similarly, the high percentage of positive sites in Karpaty (south-eastern Poland) fits with data from across the border in Slovakia, where otters are known to occur 
mainly in central and eastern parts of the country (Kadlecik 1992). The otter is virtually extirpated in both the Polish and Czech parts of Sudety, and it is interesting that a marked edge in species range along the upper Wisła in Poland (approximately in the middle of the southern state border) is precisely confirmed by data on otter distribution in the Czech Republic (Toman 1992). The small otter population in the eastern Czech Republic is linked to the Carpathian population in Poland and Slovakia, while it is completely isolated from the two other Czech populations (Toman 1992).

The Odra catchment area connects Polish and German otter populations. In Germany, the otter is generally confined to the eastern part (former GDR), and the population follows a general pattern of decline from east to west (Stubbe 1978, 1989, Reuther 1992). The comparison of percentage of positive sites in Pomorze in Poland (almost 100\%) and in northern Lower Saxony (1.6\% positive according to Binner 1992) shows a dramatic decrease in otter abundance along the Middle European Lowland. Recent signs of increase of otter range in eastern Germany (Reuther 1993) may be partly contributed by dispersal of otters from west Poland. Relatively high otter abundance in most of Poland is of special importance to the distribution of the species in Europe, as it links thriving eastern otter populations with recovering population in Germany. While the absence of otters in one area in central Poland is of a local character, the extirpation of the species in Polish and Czech parts of Sudety Mts creates the barrier to the continuous distribution of the species in central Europe.

Acknowledgements: We would like to thank all students who helped in the field survey, especially: M. Bartoszewicz, M. Faruga, A. Pabin, A. Wagner, T. Ziemka. This project was supported by the Prince's Trust and Charity Know How.

\section{References}

Baranauskas K. and Mickevicius E. 1995. The new data on the otters in Lithuania. Lutreola 5: 11-14.

Bieniek M. 1988. The otter, Lutra lutra (L.) in Poland's national parks. Ochrona Przyrody 46: 195-215. [In Polish with English summary]

Bieniek M. 1992. Otter Lutra lutra (Linné, 1758). [In: Polish Red Data Book of Animals. Z. Głowaciński, ed]. PWRiL, Warszawa: 76-77. [In Polish with English summary]

Binner U. 1992. Otter-Verbreitungserhebung Nord-Niedersachsen. [In: Otterschutz in Deutschland. C. Reuther, ed]. Habitat 7: 81-83.

Brzeziński M. 1991a. The occurence of the otter Lutra lutra, in the Romincka Primeval Forests. Chrońmy Przyrodę Ojczystą 47: 88-90. [ In Polish]

Brzeziński M. 1991b. Distribution of the river otter Lutra lutra L. in the Bieszczady Mountains. Przegląd zoologiczny 35: 397-406. [In Polish with English summary]

Buchalczyk T. 1983. Lutra lutra (Linnaeus, 1758). [In: Atlas of Polish mammals. Z. Pucek and J. Raczyński, eds]. PWN, Warszawa: 149, map 143.

Chapman P. J. and Chapman L. L. 1982. Otter survey of Ireland 1980-81. Vincent Wildlife Trust, London: $1-40$.

Delibes M. (ed) 1990. La nutria (Lutra lutra) en Espana. ICONA, Madrid: 1-198.

Green J. and Green R. 1980. Otter survey of Scotland 1977-79. Vincent Wildlife Trust, London: 1-46. 
Green J. and Green R. 1981. The otter (Lutra lutra L.) in western France. Mammal Review 11: 181-187.

GUS. 1994. Environmental Protection 1993. Główny Urząd Statystyczny, Warszawa: 450. [In Polish]

Jamrozy G. 1994. The occurrence, distribution and population of game mammals in the Polish Carpathian Mountains. Zeszyty Naukowe Akademii Rolniczej im. H. Kołątaja w Krakowie 190: 1-104. [In Polish with English summary]

Jenkins D. and Burrows G. O. 1980. Ecology of otters in northern Scotland. III. The use of feaces as indicators of otter (Lutra lutra) density and distribution. Journal of Animal Ecology 49: 755-774.

Kadlecik J. 1992. Distribution of Eurasian otter (Lutra lutra L., 1758) in Slovakia - the present state of knowledge. Bulletin Vydra 3: 54-59. [In Slovak with English summary]

Kemenes I. 1991. Otter distribution, status and conservation problems in Hungary. IUCN Otter Specialist Group Bulletin 6: 20-23.

Kondracki J. 1988. Physical geography of Poland. PWN, Warszawa: 1-464. [In Polish]

Korol R., Jaśniewicz E., Bożek A., Szyjkowska U., Zelent B. and Czapliński M. 1994. Atlas of pollution of rivers in Poland in 1990-1992. Biblioteka Monitoringu Środowiska, Warszawa: 1-208. [In Polish]

Leszczycki S. 1978. [Geographical studies]. Książka i Wiedza, Warszawa: 1-501. [In Polish]

Leszczycki S. (ed) 1994. Atlas of resources, values and degradation of geographical environment of Poland. Agencja Reklamowo-Wydawnicza A. Grzegorczyk, Warszawa: 1-97 maps.

Macdonald S. M. 1983. The status of the otter in the British Isles. Mammal Review 13: 11-23.

Macdonald S. M. 1990. Surveys. [In: Otters; an action plan for their conservation. P. Foster-Turley, S. Macdonald and C. Mason, eds]. IUCN Species Survival Commision, Gland: 8-10.

Macdonald S. M. and Mason C. F. 1982a. The otter Lutra lutra in central Portugal. Biological Conservation 22: 207-215.

Macdonald S. M. and Mason C. F. 1982b. Otters in Greece. Oryx 16: 240-244.

Macdonald S. M. and Mason C. F. 1983. Some factors influencing distribution of otters (Lutra lutra). Mammal Review 13: 1-10.

Macdonald S. M. and Mason C. F. 1990a. Threats. [In: Otters; an action plan for their conservation. P. Foster-Turley, S. Macdonald and C. Mason, eds]. IUCN Species Survival Commision, Gland: 11-14.

Macdonald S. M. and Mason C. F. 1990b. Action plan for European otters. [In: Otters; an action plan for their conservation. P. Foster-Turley, S. Macdonald and C. Mason, eds]. IUCN Species Survival Commision, Gland: 29-40.

Macdonald S. M. and Mason C. F. 1994. Status and conservation needs of the otter (Lutra lutra) in the western Palaearctic. Nature and Environment 67: 1-54

Madsen A. B. and Nielsen C. E. 1986. The occurrence of otter (Lutra lutra L.) in Denmark 1984-86. Flora og Fauna 92: 60-62. [In Danish with English summary]

Mason C. F. 1989. Water pollution and otter distribution: a review. Lutra 32: 97-131.

Mickevicius E. 1993. The otter in Lithuania. IUCN Otter Specialist Group Bulletin 8: 29-31.

Pielowski Z. 1980. Die Situation des Fischotters in Polen. [In: Der Fischotter in Europa - Verbreitung, Bedrohung, Erhaltung. C. Reuther and C. Festetics, eds]. Selbstverlag, Oderhaus, Göttingen: 183-185.

Reuther C. 1992. Aktion Fischotterschutz e. V. activities 1991-92. IUCN Otter Specialist Group Bulletin 7: 16-19.

Reuther C. 1993. Aktion Fischotterschutz e. V. (German Campaign for Otter Protection): activities 1992. IUCN Otter Specialist Group Bulletin 8: 21-22.

Romanowski J. 1984. The occurrence of the otter Lutra lutra (Linnaeus, 1758) in Poland in the light of inquiry to hunters. Przegląd zoologiczny 28: 397-406. [In Polish with English summary]

Romanowski J., Brzeziński M. and Cygan J. P. 1996. Notes on the technique of the otter field survey. Acta Theriologica 41: 199-204. 
Sidorovich V. E. 1991. Structure, reproductive status and dynamics of the otter population in Byelorussia. Acta Theriologica 36: 153-161.

Sidorovich V. E. and Lauzhel G. O. 1992. Numbers of otters and approach to population estimation in Byelorussia. IUCN Otter Specialist Group Bulletin 7: 13-16.

Sikora S. 1984. Studies on the occurence of Otter Lutra lutra (L.) in Poland. Poznańskie Towarzystwo Przyjaciół Nauk, Prace Komisji Nauk Rolniczych i Leśnych, Poznań 57: 253-268. [In Polish with English summary]

Strachan R., Birks J. D. S., Chanin P. R. F. and Jefferies D. 1990. Otter survey of England 1984-1986. Nature Conservancy Council, Peterborough: 1-67.

Stubbe M. 1978. Der Fischotter Lutra lutra (L., 1758) in den mittleren Bezirken der DDR. Hercynia 15: $77-105$.

Stubbe M. 1989. Verbreitung und Ökologie des Fischotters Lutra lutra (L., 1758) in der DDR. Populationsökologie marderartiger Säugetiere, Wissenschaftliche Beiträge der Universität, Halle 1: $13-33$.

Toman A. 1992. First results of "Action otter". Bulletin Vydra 3: 9-13. [In Czech with English summary]

Włodek K. 1980. Der Fischotter in der Provinz Pomorze Zachodnie (West Pommern) in Polen. [In: Der Fischotter in Europa - Verbreitung, Bedrohung, Erhaltung. C. Reuther and C. Festetics, eds]. Selbstverlag, Oderhaus, Göttingen: 187-194.

Włodek K., Łapiński W., Gielo M., Sobolewski H. and Rösler A. 1989. Expansion des Fischotters Lutra lutra (L., 1758) in Polen. Populationsökologie marderartiger Säugetiere, Wissenschaftliche Beiträge der Universität, Halle 1: 44-54.

Received 21 March 1995, revised 26 January 1996, accepted 1 February 1996. 